\title{
A Short, Efficient, and Stereoselective Synthesis of Piperine and its Analogues
}

\author{
Adriano Bauer ${ }^{\diamond}$ \\ Jun-Hyun Nam \\ Nuno Maulide*(D) \\ Institute of Organic Chemistry, University of Vienna, Währinger \\ Straße 38, 1090 Vienna, Austria \\ nuno.maulide@univie.ac.at \\ $\diamond$ These authors contributed equally to this work \\ Published as part of the 30 Years SYNLETT - Pearl Anniversary Issue
}

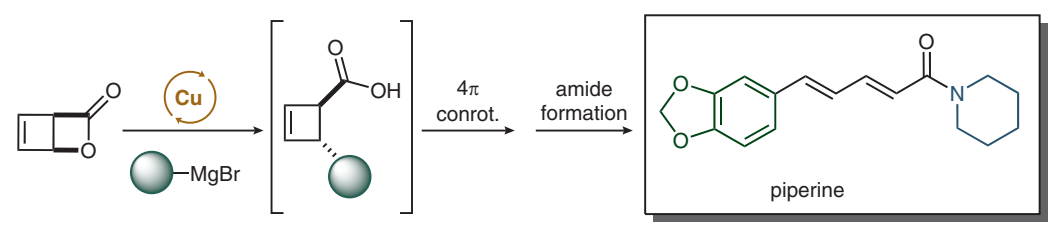

$\checkmark$ Piperine synthesized in quantitative yield $\checkmark$ Full stereocontrol

Modulation of the aryl and the amide moiety
Received: 26.11.2018

Accepted after revision: 16.12 .2018

Published online: 14.01 .2019

DOI: 10.1055/s-0037-1611652; Art ID: st-2018-b0768-I

License terms: Cc)

Abstract A quantitative synthesis of piperine from commercially available starting material is presented. The synthesis relies on a stereoselective nucleophilic attack of an in situ generated cuprate onto a cyclobutene lactone. The so-formed aryl-substituted cyclobutene spontaneously undergoes a conrotatory $4 \pi$-electrocyclic ring opening to form the 4-aryl pentadienoic acid as a single diastereoisomer. The high-yielding synthesis can be easily modulated on the aryl and on the amide moiety for the synthesis of a wide range of piperine analogues.

Key words total synthesis, piperine, alkaloid, cyclobutene, pericyclic reaction, stereoselective, organometallic chemistry

In 1820, the Danish physicist and chemist Hans Christian Ørstedt, pursuing an interest in the isolation of 'new alkalis', reported a new alkaloid from pepper (piper nigrum), which he called piperine. ${ }^{1}$ Piperine would ultimately gain the attention of the chemistry and physiology communities $^{2}$ mostly due to its wide range of biological activities. This was foreshadowed by the original communication itself, where Ørstedt noted that an ethanolic solution of piperine has an 'exceptionally pungent taste'. ${ }^{1}$ The pungency of piperine can be attributed to its agonistic nature towards the heat- and acidity-sensing TRPV ion channels, which are associated with temperature and pain regulation in the human body. ${ }^{2 a, b}$ A range of human disorders are linked to the overexpression of TRPV1, including inflammatory bowel disease (ulcerative colitis and Crohn's disease) and chronic breast pain. ${ }^{2 c}$ Studies have shown that piperine is a potent desensitizer of human TRPV1, rendering its structure a potent scaffold for the design of improved TRPV1 agonists. ${ }^{2 c, d}$

Moreover, piperine has been recently identified as an allosteric modulator of the $\gamma$-amino butyric acid type $A$ $\left(G_{A B A}\right)$ receptor. ${ }^{3 a}$ The mode of action of piperine is thus analogous to commonly used drugs such as benzodiazepines, widely used as sleep-inducing agents. ${ }^{3 b, c}$ In addition, it has been shown that piperine derivatives are efficient inhibitors of vascular smooth muscle cell proliferation. ${ }^{4}$ Antidepressant $^{5 \mathrm{~b}}$ and antitumor ${ }^{5 \mathrm{c}}$ activities along with insecticidal properties ${ }^{5 \mathrm{~d}}$ are also attributed to this intriguing molecule which can be technically found in almost every modern kitchen in the world.

Despite the numerous demonstrated beneficial therapeutic properties of piperine, biological applications are limited by its poor solubility in aqueous media. ${ }^{6}$ This implies that new synthetic routes towards piperine analogues are highly desirable.

Piperine can be easily extracted ${ }^{5}$ and its basic hydrolysis, yielding piperic acid, opens up the preparation of many amide analogues for biological evaluation. ${ }^{7}$ This approach is unfortunately limited by nonexchangeability of the aryl moiety. Most approaches for the synthesis of 1-carbonyl-4aryl-substituted dienes typically make use of a $(2+2),(3+$ $1)$, or a $(1+2+1)$ carbon disconnection. In this regard Wittig olefination, ${ }^{8}$ olefin metathesis, ${ }^{9}$ palladium-catalyzed cross-coupling, ${ }^{10}$ or ruthenium-catalyzed vinyl-alkyne coupling ${ }^{11}$ have been employed as dominant strategies. 
a) Mihovilovic et al. (ref. 12)

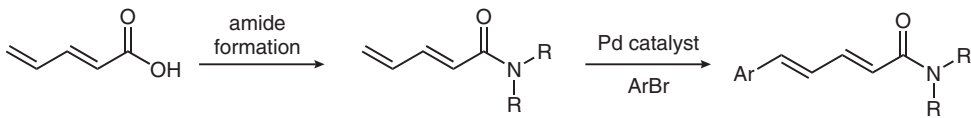

b) Chandrasekhar et al. (ref. 13)

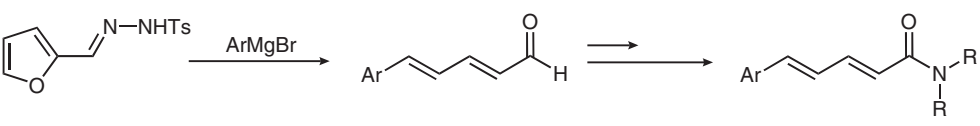

c) This work
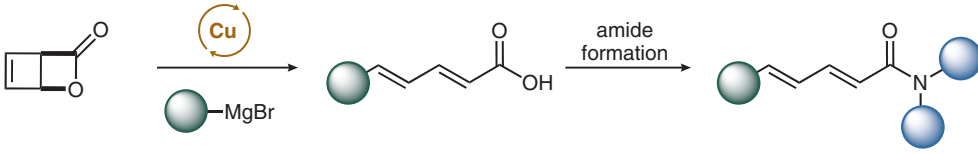

Scheme 1 Previous work and this work

A rather unconventional approach is the direct coupling of the aryl moiety with the diene or a diene precursor. Mihovilovic and coworkers reported an efficient Heck reaction approach in which an aryl bromide is coupled to a pentadienoic amide (Scheme 1, a).,12 Another intriguing, earlier approach, relies on the addition of a Grignard reagent to a furfural hydrazone, which rearranges to the corresponding pentadienal under the reaction conditions (Scheme 1, b). ${ }^{13}$

Herein we would like to present a different strategy towards the synthesis of piperine analogues. The bicyclo [2.2.0] lactone $\mathbf{2}$ and its derivatives have been deployed in previous work by our group and others as a versatile electrophile. ${ }^{14}$ In particular, we have shown that copper-mediated nucleophilic addition is a very robust method for a trans-selective allylic substitution of $2 .^{14 \mathrm{f}}$

The installation of an electron-rich moiety (such as -OR or $-\mathrm{N}_{3}$ ) in this position has been earlier shown to facilitate a subsequent, spontaneous $4 \pi$-electrocyclic opening. This is likely due to a push-pull relationship between the carboxylic acid and the electron-donating substituent. ${ }^{15}$

We hypothesized that an aryl moiety might be sufficiently electron donating in order to induce a similar pushpull effect and enable facile electrocyclic ring opening, either spontaneously at room temperature or upon mild heating. Importantly, the transient trans-configured cyclobutene should undergo opening according to a thermally allowed, conrotatory movement torquoselective for the $E, E$ diene product.

Lactone $\mathbf{2}$ was prepared in quantitative yield photochemically, as previously reported. ${ }^{14 f}$ In the event, we found that addition of the in situ formed cuprate (from its corresponding Grignard reagent 3a) directly led to piperic acid (4a) as the sole product in a single, quantitative step. ${ }^{16}$ As expected, 4a was formed exclusively as the E,E-diene isomer in a clean reaction. ${ }^{17}$ Straightforward amide formation via acyl chloride substitution with piperidine afforded piperine in more than $95 \%$ isolated yield. ${ }^{18}$ Through the route presented herein, this alkaloid was thus available in only three quantitative steps from pyrone $\mathbf{1}$ and with full stereoselectivity (Scheme 2).

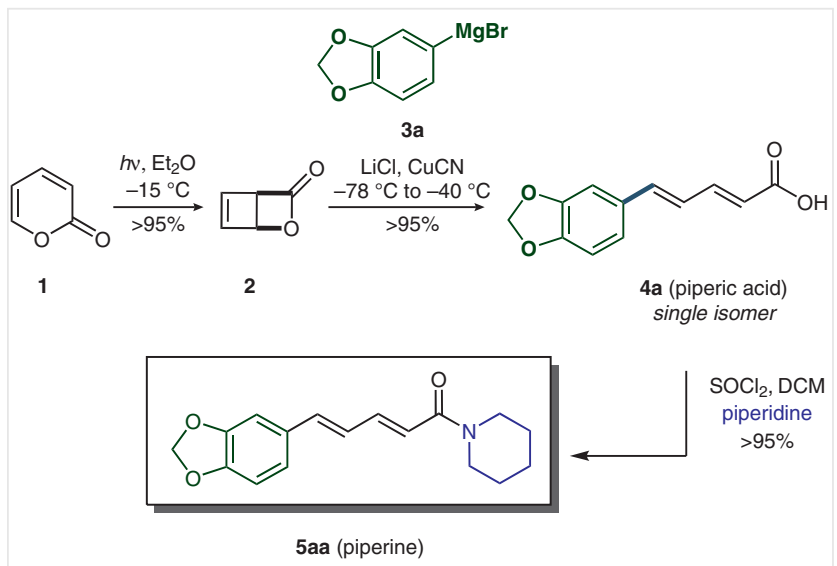

Scheme 2 A simple three-step synthesis of piperine

Encouraged by these results, we investigated the synthesis of three different piperic acid analogues by using different Grignard reagents for the ring opening of bicyclolactone $\mathbf{2}$. The 5-phenylpentadienoic acid (4b) was prepared in quantitative yield, while the para-methoxyphenyl- and the 2-thiophenyl- analogues were formed in slightly lower yields. Nevertheless, geometric selectivity was excellent in all cases (Scheme 3). ${ }^{19}$ Finally, the corresponding amides were formed as before via standard acyl chloride substitution (Scheme 4). ${ }^{18}$ It should be noted that amides $\mathbf{5 b b}$ and $\mathbf{5 c b}$ have been previously reported to enhance $G A B A_{A}$-induced chloride currents more strongly than natural piperine $\left(789 \% \pm 72 \%\right.$ and $883 \% \pm 70 \%$, respectively). ${ }^{12}$ 

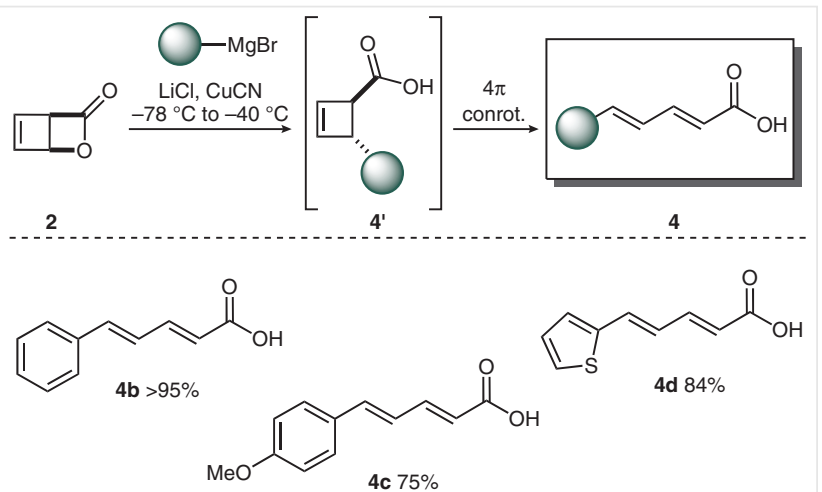

Scheme 3 Synthesis of piperic acid analogues 4
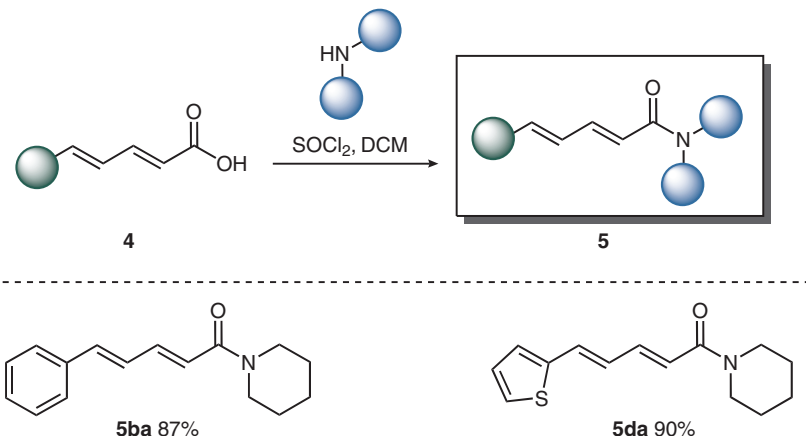

5ba $87 \%$<smiles>COc1ccc(/C=C/C=C/C(=O)N2CCCCC2)cc1</smiles><smiles>CCCCN(CCCC)C(=O)/C=C/C=C/c1ccccc1</smiles>

Scheme 4 Synthesis of piperine analogues 5

In conclusion, we herein presented a conceptually new approach to the synthesis of 4-aryl-substituted pentadienoic acids and their amides in excellent yield and geometrical stereoselectivity. ${ }^{20-26}$ This enabled a preparation of the natural product piperine in quantitative yield over three steps from commercially available 2-pyrone $\mathbf{1}$. Analogues can be readily synthesized through this modular and operationally simple procedure.

\section{Funding Information}

Funding by the Austrian Research Fund (FWF Project P27194) is gratefully acknowledged.

\section{Acknowledgment}

We are grateful to the University of Vienna for continued generous support of our research programs.

\section{Supporting Information}

Supporting information for this article is available online at https://doi.org/10.1055/s-0037-1611652.

\section{References and Notes}

(1) Ørstedt, H. C. Journal für Chemie und Physik 1820, 29, 80.

(2) (a) Bley, K. R. Exper. Opin. Invest. Drugs 2004, 13, 1445. (b) Gavva, N. R.; Bannon, A. W.; Surapaneni, S.; Hovland, D. N. Jr; Lehto, S. G.; Gore, A.; Juan, T.; Deng, H.; Han, B.; Klionsky, L.; Kuang, R.; Le, A.; Tamir, R.; Wang, J.; Youngblood, B.; Zhu, D.; Norman, M. H.; Magal, E.; Treanor, J. J. S.; Louis, J.-C. J. Neurosci. 2007, 27, 3366. (c) Szallasi, A. Trends in Pharm. Sci. 2005, 26, 437. (d) Gunthorpe, M. J.; Szallasi, A. Curr. Pharm. Design 2008, $14,32$.

(3) (a) Zaugg, J.; Baburin, I.; Strommer, B.; Kim, H.-J.; Hering, S.; Hamburger, M. J. Nat. Prod. 2010, 73, 185. (b) Whiting, P. J. Curr. Opin. Pharmacol. 2006, 6, 24. (c) Riss, J.; Cloyd, J.; Gates, J.; Collins, S. Acta Neurol. Scand. 2008, 118, 781.

(4) Mair, E. M.; Liu, R.; Atanasov, A. G.; Wimmer, L.; NemetzFiedler, D.; Sider, N.; Heiss, E. H.; Mihovilovic, M. D.; Dirsch, V. M.; Rollinger, J. M. Planta Med. 2015, 81, 1065.

(5) (a) Vasavirma, K.; Upender, M. Int. J. Pharm. Pharm. Sci. 2014, 6, 34. (b) Li, S.; Wang, C.; Koike, K.; Nikaido, R.; Wang, M. W. J. Asian Nat. Prod. Res. 2007, 9, 421. (c) Sunila, E. S.; Kuttan, G. J. Ethnopharmacol. 2004, 90, 339. (d) Tavares, W. S.; Cruz, I.; Petacci, F.; Freitas, S. S.; Serrao, J. E.; Zanuncio, J. C. J. Med. Plants Res. 2011, 5, 5301.

(6) Gorgani, L.; Mohammadi, M.; Najafpour, G. D.; Nikzad, M. Compr. Rev. Food Sci. Food Saf. 2017, 16, 124

(7) Umadevi, P.; Deepti, K.; Venugopal, V. R. Med. Chem. Res. 2013, $22,5466$.

(8) (a) Olsen, R. A.; Spessard, G. O. J. Agric. Food Chem. 1981, 29, 942. (b) Schobert, R.; Siegfried, S.; Gordon, G. J. J. Chem. Soc., Perk. Trans. 1 2001, 2393. (c) O'Brien, C. J.; Lavigne, F.; Coyle, E. E.; Holohan, A. J.; Doonan, B. J. Chem. Eur. J. 2013, 19, 5854.

(9) Lipshutz, B. H.; Ghorai, S.; Boskovic, Z. V. Tetrahedron 2008, 64, 6949.

(10) (a) Abarbri, M.; Parrain, J.-L.; Duchene, A. Synth. Commun. 1998, 28, 239. (b) Naskar, D.; Roy, S. Tetrahedron 2000, 1369.

(11) Schabel, T.; Plietker, B. Chem. Eur. J. 2013, 19, 6938.

(12) Wimmer, L.; Schönbauer, D.; Pakfeifer, P.; Schöffmann, A.; Khom, S.; Hering, S.; Mihovilovic, M. D. Org. Biomol. Chem. 2015, 13, 990.

(13) Chandrasekhar, S.; Venkat Reddy, M.; Srinivasa Reddy, K.; Ramarao, C. Tetrahedron Lett. 2000, 41, 2667.

(14) (a) Frébault, F.; Luparia, M.; Oliveira, M. T.; Goddard, R.; Maulide, N. Angew. Chem. Int. Ed. 2010, 49, 5672. (b) Luparia, M.; Audisio, D.; Maulide, N. Synlett 2011, 735. (c) Luparia, M.; Oliveira, M. T.; Audisio, D.; Frébault, F.; Goddard, R.; Maulide, N. Angew. Chem. Int. Ed. 2011, 50, 12631. (d) Audisio, D.; Luparia, M.; Oliveira, M. T.; Kluett, D.; Maulide, N. Angew. Chem. Int. Ed. 2012, 51, 7314. (e) Souris, C.; Frébault, F.; Audisio, D.; Farès, C.; Maulide, N. Synlett 2013, 24, 1286. (f) Souris, C.; Misale, A.; Chen, Y.; Luparia, M.; Maulide, N. Org. Lett. 2015, 17, 4486. (g) Gutekunst, W. R.; Baran, P. S. J. Am. Chem. Soc. 2011, 133, 19076. (h) Nistanaki, S.; Boralsky, L. A.; Pan, R. D.; Nelson, H. ChemRxiv. 2018, DOI: 10.26434/chemrxiv.7245167.v2.

(15) For spontaneous ring opening of cyclobutenes, see: (a) Binns, F.; Hayes, R.; Ingham, S.; Saengchantara, S. T.; Turner, R. W.; Wallace, T. W. Tetrahedron 1992, 48, 515. (b) Binns, F.; Hayes, R.; 
Hodgetts, K. J.; Saengchantara, S. T.; Wallace, T. W.; Wallis, C. J. Tetrahedron 1996, 52, 3631. (c) Sheldrake, H. M.; Wallace, T. W.; Wilson, C. P. Org. Lett. 2005, 7, 4233. (d) Ingham, S.; Turner, R. W.; Wallace, T. J. Chem. Soc,. Chem. Commun. 1985, 1664.

(16) Magnesium turnings ( $1.60 \mathrm{mmol}, 3.0$ equiv.) were suspended in a flamed-dried Schlenk tube containing anhydrous THF ( $3 \mathrm{~mL})$ which was previously flushed with argon. A solution of an arylbromide in dry THF ( $1.60 \mathrm{mmol}, 1.0$ equiv. in $2 \mathrm{~mL}$ ) was added dropwise under stirring. The mixture was stirred at room temperature until the magnesium was fully solubilized. $\mathrm{LiCl}$ (3.20 mmol, 6 equiv.) was flame-dried in another Schlenk tube under vacuum. After flushing with argon and cooling to room temperature CuCN (1.60 mmol, 3 equiv.) was added to the solid, suspended in anhydrous THF ( $5 \mathrm{~mL})$, and stirred for $20 \mathrm{~min}$ at room temperature. The green solution was cooled down to $-40{ }^{\circ} \mathrm{C}$, followed by an addition of the Grignard $(1.60 \mathrm{mmol}, 3$ equiv.) and further stirred for $40 \mathrm{~min}$. Afterwards, the reaction mixture was cooled down to $-78^{\circ} \mathrm{C}$. After stirring for $15 \mathrm{~min}$, an ethereal solution of lactone $2(0.53 \mathrm{mmol}, 1$ equiv. $)$ was added, and the reaction mixture was allowed to warm up slowly to $-30{ }^{\circ} \mathrm{C}$. The reaction was quenched by the dropwise addition of aqueous $\mathrm{HCl}(1 \mathrm{M}, 5 \mathrm{~mL})$, and the obtained solution was warmed up quickly to room temperature (the dry ice bath was removed). Upon dilution with EtOAc $(10 \mathrm{~mL})$, the reaction mixture was extracted and washed with aqueous $\mathrm{HCl}(1 \mathrm{M})$ whereby the aqueous layer was neutralized with sufficient $\mathrm{NaOH}(5 \mathrm{M})$ in order to deprotonate the formed hydrocyanic acid. The organic layer was dried over $\mathrm{Na}_{2} \mathrm{SO}_{4}$, filtered, and the solvent was removed under reduced pressure. Purification of the crude acid was performed via column chromatography (EtOAc/heptane/acetic acid 10\%:89\%:1\%) to yield the 4-aryl-substituted pentadienoic acid as a solid.

(17) Copper(I) iodide lead only to messy reactions with traces of desired product.

(18) In a flame-dried Schlenk tube the carboxylic acid 4 (0,20 mmol, 1.0 equiv.) was dissolved in anhydrous DCM $(1 \mathrm{~mL})$, followed by the addition of thionyl chloride $(0.40 \mathrm{mmol}, 2.0$ equiv.). The reaction was stirred at room temperature until the solid dissolved completely. Heating to reflux can be applied for a faster conversion. Thereafter, volatiles were removed under reduced pressure, and the flask was flushed with argon again (an argonfilled balloon was attached to the rotary evaporator). To the resulting residue anhydrous DCM was added $(1 \mathrm{~mL})$, and the amine was added dropwise $(0.40 \mathrm{mmol}, 2.0$ equiv. $)$. Afterwards, the solution was stirred for $1 \mathrm{~h}$ at room temperature. Finally, the reaction mixture was quenched and washed with saturated aqueous $\mathrm{NaHCO}_{3}$ solution, and the aqueous layer was extracted 3 times with DCM. The combined organic layer was dried over $\mathrm{Na}_{2} \mathrm{SO}_{4}$, filtered, and volatiles were removed under reduced pressure to yield the pure amide. Further purification via flash chromatography gave the desired amide. (Gradient: EtOAc/heptane 10:90 to EtOAc/heptane 60:40).

(19) The crude NMR of $\mathbf{4 b}, \mathbf{4} \mathbf{c}$, and $\mathbf{4 d}$ suggested that traces $(<5 \%$ NMR yield) of another geometrical isomer was present which was easily separated by column chromatography. We were not able to find this side product after purification.

(20) Kotretsou, S. I.; Georgiadis, M. P. Org. Prep. Proced. Int. 2000, 32, 161.

(21) Wani, N. A.; Singh, S.; Farooq, S.; Shankar, S.; Koul, S.; Khan, I. A.; Rai, R. Bioorg. Med. Chem. Lett. 2016, 26, 4174.

(22) Wang, Z.; He, Z.; Zhang, L.; Huang, Y.J. Am. Chem. Soc. 2018, 140, 735.

(23) Yasir, A.; Ishtiaq, S.; Jahangir, M.; Ajaib, M.; Salar, U.; Khan, K. M. Med. Chem. 2018, 14, 269.

(24) Shen, Y.; Zhou, Y.J. Chem. Soc., Perkin Trans. 1 1992, 22, 3081.

(25) Spectroscopic data of $\mathbf{1},{ }^{20} \mathbf{2},{ }^{14 \mathrm{f}} \mathbf{4 a},{ }^{21} \mathbf{4 b},{ }^{22} \mathbf{4 c},{ }^{10 \mathrm{~b}} \mathbf{4 d},{ }^{10 \mathrm{~b}} \mathbf{5} \mathbf{a a},{ }^{23} \mathbf{5 b a},{ }^{24}$ $\mathbf{5} \mathbf{c a},{ }^{4} \mathbf{5 b b},{ }^{12}$ and $\mathbf{5} \mathbf{c b}^{12}$ matches previously reported spectra.

(26) Characterization of $5 \mathrm{da}$

${ }^{1} \mathrm{H}$ NMR $\left(400 \mathrm{MHz}, \mathrm{CDCl}_{3}\right): \delta=7.37$ (ddd, J = 14.6, $11.1,0.6 \mathrm{~Hz}, 1$ $\mathrm{H}), 7.23(\mathrm{~d}, \mathrm{~J}=5.0 \mathrm{~Hz}, 1 \mathrm{H}), 7.07(\mathrm{~d}, \mathrm{~J}=3.5 \mathrm{~Hz}, 1 \mathrm{H}), 7.01-6.93(\mathrm{~m}$, $2 \mathrm{H}), 6.70(\mathrm{dd}, \mathrm{J}=15.3,11.2 \mathrm{~Hz}, 1 \mathrm{H}), 6.45(\mathrm{~d}, \mathrm{~J}=14.7 \mathrm{~Hz}, 1 \mathrm{H})$, 3.60 (d, J = 24.6 Hz, $2 \mathrm{H}), 3.52$ (s, $2 \mathrm{H}), 1.71-1.55$ (m, $7 \mathrm{H}) .{ }^{13} \mathrm{C}$ NMR $\left(151 \mathrm{MHz}, \mathrm{CDCl}_{3}\right): \delta=165.40,142.03,131.18,127.97$, 127.90, 126.80, 125.99, 120.62, 47.04, 43.38, 26.86, 25.74, 24.78. HRMS (ESI): $\mathrm{m} / \mathrm{z}$ calcd for $[\mathrm{M}+\mathrm{Na}]^{+}: 270.0923$; found: 270.0926. ATR-FTIR: 3001, 2935, 2854, 2237, 1631, 1588, 1513, 1435, 1358, 1295, 1254, 1222, 1190, 1133, 1118, 1043, 1018, $990,953,907,872,853,833,805,726,644,575,543,532 \mathrm{~cm}^{-1}$. 